Davies, M. B., J. Austin, ANd D. A. Partridge. 1991. Vitamin C: Its chemistry and biochemistry. Royal Society of Chemistry, Cambridge, United Kingdom.

DiAMOND, J. M. 1986. Why do disused proteins become genetically lost or repressed? Nature 351: 565-566.

Elliot, O., N. J. Yess, AND D. M. Hegsted. 1966. Biosynthesis of ascorbic acid in the tree shrew and the slow loris. Nature 212:739-740.

ENGLARD, S., AND S. SEIFTER. 1986. The biochemical functions of ascorbic acid. Annual Review of Nutrition 6:365-406.

Fitch, W. M. 1971. Towards defining the course of evolution: minimal change for a specific tree topology. Systematic Zoology 20:406-416.

Hanssen, K., H. J. Grav, J. B. Steen, AND H. Lysnes. 1979. Vitamin C deficiency in growing Willow Ptarmigan (Lagopus lagopus lagopus). Journal of Nutrition 109:2260-2278.

HORNIG, D. 1975. Distribution of ascorbic acid , metabolites and analogues in man and animals. Annals of the New York Academy of Science 258: 103-118.

JACOB, R. A. 1994. Vitamin C. Pages 432-448 in Modern nutrition in health and disease, vol. 1 (M. E. Shils, J. A. Olson, and M. Shike, Eds.). Lea and Febinger, New York.
Jenness, R., E. C. Birney, And K. L. Ayaz. 1980. Variation of L-gulonolactone oxidase activity in placental mammals. Comparative Biochemistry and Physiology 67B:195-204.

MAdDison, W. P., AND D. R. MAdDISON. 1992. MacClade (version 3): Analysis of phylogeny and character evolution. Sinauer Associates, Boston.

PAUling, L. 1970. Vitamin C and the common cold. W. H. Freeman and Company, San Francisco.

PIANKA, E. R. 1994. Evolutionary ecology. Harper Collins, New York.

POlloCK, J. I., AND R. J. MULlin. 1987. Vitamin C biosynthesis in prosimians: Evidence for the anthropoid affinity of Tarsius. American Journal of Physical Anthropology 73:65-70.

RobBins, C. T. 1993. Wildlife feeding and nutrition. Academic Press, San Diego, California.

Sibley, C. G., AND J. E. AhlQuist. 1990. Phylogeny and classification of birds: A study in molecular evolution. Yale University Press, New Haven, Connecticut.

Sibley, C. G., AND B. L. MONROE, JR. 1990. Distribution and taxonomy of birds of the world. Yale University Press, New Haven, Connecticut.

Received 3 September 1996, accepted 5 February 1997. Associate Editor: M. E. Murphy

The Auk 114(3):516-520, 1997

\title{
Sex Identification of South American Parrots (Psittacidae, Aves) Using the Human Minisatellite Probe 33.15
}

\author{
Cristina Y. MiYaki, ${ }^{1}$ J. Mauricio B. Duarte, ${ }^{2}$ Renato Caparroz, ${ }^{1,2}$ \\ Adauto L. V. Nunes, ${ }^{3}$ AND ANITA WAJNTAL ${ }^{1,4}$ \\ ${ }^{1}$ Departamento de Biologia, Universidade de São Paulo, C.P. 11,461, CEP 05422-970, São Paulo, SP, Brazil; \\ ${ }^{2}$ Departamento de Melhoramento Genético Animal, FCAVI, UNESP, \\ Rodovia Carlos Tonanni Km5-Jaboticabal, CEP 014870-000, São Paulo, SP, Brazil; and \\ ${ }^{3}$ Parque Zoológico de Sorocaba, Sorocaba, SP, Brazil
}

Many species of South American parrots are endangered, and captive breeding has become a standard procedure for species conservation. Because most South American parrots are not sexually dimorphic, an efficient means of determining the sex of individuals is an important tool in establishing and maintaining a viable breeding population in captivity.

DNA fingerprinting (Jeffreys et al. 1985) has been

\footnotetext{
${ }^{4}$ Address correspondence to this author. E-mail: aniwa@usp.br
}

applied in a variety of wild species, including birds (Burke and Bruford 1987, Wetton et al. 1987). It was used to monitor genetic variability in captive Puerto Rican Parrots (Amazona vittata; Brock and White 1992) and to establish paternity in endangered species (Mathé et al. 1993). Recently, we used DNA fingerprinting to identify the sex of Peach-fronted ( $A r$ atinga aurea) and Golden (Guaruba [Aratinga] guarouba) parakeets (Miyaki et al. 1992) and suggested that fingerprinting also could be used to determine sex in other psittacines (Miyaki et al. 1993, 1995). Here, we present results on sex determination using the human minisatellite probe 33.15 (Jeffreys et al. 
TABLE 1. Pattern of intense bands in previously sexed and unsexed parrots. F and M are number of females and males; $\mathrm{N}$ and $\mathrm{Nb}$ are number of individuals and number with intense bands, respectively.

\begin{tabular}{|c|c|c|c|c|c|c|c|}
\hline \multirow[b]{2}{*}{ Species } & \multicolumn{4}{|c|}{ Sexed } & \multicolumn{2}{|c|}{ Unsexed } & \multirow[b]{2}{*}{ Tota } \\
\hline & $\mathrm{F}$ & $\mathbf{M}$ & Method ${ }^{\mathbf{a}}$ & Bands $^{\mathrm{b}}$ & $\mathrm{N}$ & $\mathrm{Nb}$ & \\
\hline Amazona aestiva aestiva & 5 & 8 & $\overline{\mathrm{k}}$ & - & 10 & 0 & 23 \\
\hline Amazona aestiva xanthopteryx & 1 & 3 & $\mathrm{k}$ & - & 0 & 0 & 4 \\
\hline Amazona amazonica & 2 & 2 & $\mathrm{k}$ & - & 2 & 0 & 6 \\
\hline Amazona autumnalis diadema & 1 & 0 & $\mathrm{k}$ & - & 1 & 0 & 2 \\
\hline Amazona brasiliensis & 2 & 2 & $\mathrm{k}, \mathrm{l}$ & - & 7 & 0 & 11 \\
\hline Amazona dufresniana rhodocorytha & 0 & 0 & & & 4 & 0 & 4 \\
\hline Amazona farinosa & 0 & 2 & $\mathrm{k}$ & - & 3 & 0 & 5 \\
\hline Amazona festiva & 0 & 2 & $\mathrm{k}$ & - & 4 & 0 & 6 \\
\hline Amazona ochrocephala xantholaema & 1 & 1 & $b$ & - & 5 & 0 & 7 \\
\hline Amazona pretrei & 3 & 3 & $\mathrm{~d}$ & - & 4 & 0 & 10 \\
\hline Amazona vinacea & 2 & 4 & $\mathrm{k}, \mathrm{b}$ & - & 6 & 0 & 12 \\
\hline Amazona xanthops & 1 & 0 & $\mathbf{k}$ & - & 4 & 0 & 5 \\
\hline Anodorhynchus hyacinthinus & 3 & 5 & k & + & 55 & 32 & 63 \\
\hline Anodorhynchus leari & 1 & 1 & $\mathrm{k}, 1$ & + & 1 & 1 & 3 \\
\hline Ara auricollis & 2 & 1 & k & + & 1 & 1 & 4 \\
\hline Ara ararauna & 3 & 2 & $\mathrm{k}, \mathrm{b}$ & + & 12 & 8 & 17 \\
\hline Ara chloroptera & 2 & 5 & $\mathrm{k}, \mathrm{b}$ & + & 15 & 4 & 22 \\
\hline Ara macao & 2 & 5 & $\mathrm{k}$ & + & 9 & 4 & 16 \\
\hline Ara manilata & 2 & 1 & k & + & 7 & 4 & 10 \\
\hline Ara maracana & 4 & 1 & k & + & 2 & 0 & 7 \\
\hline Ara nobilis & 2 & 4 & k & + & 11 & 3 & 17 \\
\hline Aratinga acuticaudatta & 1 & 1 & k & + & 0 & - & 2 \\
\hline Aratinga aurea & 2 & 2 & k & + & 32 & 14 & 36 \\
\hline Aratinga leucophthalmus & 1 & 1 & b & + & 10 & 5 & 12 \\
\hline Aratinga mitrata & 0 & 0 & & & 2 & 1 & 2 \\
\hline Aratinga solstitialis auricapilla & 0 & 0 & & & 8 & 2 & 8 \\
\hline Aratinga solstitialis jandaya & 0 & 0 & & & 4 & 4 & 4 \\
\hline Cyanopsitta spixii & 3 & 4 & $\mathrm{k}$ & + & 0 & - & 7 \\
\hline Deroptyus accipitrinus & 1 & 1 & b & - & 0 & - & 2 \\
\hline Guaruba guarouba & 3 & 3 & $k, b$ & + & 19 & 9 & 25 \\
\hline Nandayus nenday & 2 & 0 & $\mathrm{~b}$ & + & 21 & 10 & 23 \\
\hline Pionites leucogaster & 1 & 1 & $\mathrm{k}$ & - & 4 & 0 & 6 \\
\hline Pionopsitta pileata & 1 & 1 & $\mathrm{~d}$ & - & 6 & 0 & 8 \\
\hline Pionus menstruus & 2 & 2 & b & - & 7 & 0 & 11 \\
\hline Pyrrhura egregia & 1 & 0 & $\mathbf{b}$ & - & 1 & 0 & 2 \\
\hline Pyrrhura frontalis & 1 & 1 & $\mathbf{b}$ & - & 2 & 0 & 4 \\
\hline Pyrrhura picta & 1 & 1 & $\mathbf{b}$ & - & 3 & 0 & 5 \\
\hline Triclaria malachitacea & 1 & 1 & $\mathrm{~d}$ & - & 0 & - & 2 \\
\hline
\end{tabular}

a, karyotype analysis; l, laparoscopy; b, breeding behavior; d, sexual dimorphism.

Female-specific bands: -, absent; +, present.

1985 ) in 36 species belonging to 13 genera of South American parrots.

Methods.-Blood samples were collected from birds belonging to aviculturists and official establishments in Brazil. For some individuals, sex was determined by karyotyping, laparoscopy, or breeding behavior. Whenever possible, growing feathers (ca. 25 days old) were collected from birds whose sex was unknown and processed for karyotype analysis. Chromosome preparation and analysis followed Duarte and Caparroz (1995). The species and number of individuals studied are shown in Table 1.

The protocols used to obtain multilocus fingerprints followed Bruford et al. (1992). For each bird, 5 $\mu \mathrm{g}$ of genomic DNA were digested with the restric- tion enzyme $\mathrm{MboI}$ (for Amazona) or HaeIII (for the other genera). Fragments were separated by electrophoresis through a $30-\mathrm{cm}$ long $1 \%$ horizontal agarose gel. Electrophoresis was stopped when the 2-kilobase (kb) marker band had migrated to the bottom of the gel. The fractionated DNA fragments were transferred onto a nylon membrane by standard capillary Southern blotting (Sambrook et al. 1989).

The membrane was hybridized with minisatellite 33.15 probe (Jeffreys et al. 1985), which was labeled with $\left[\alpha-{ }^{32} \mathrm{P}\right] \mathrm{dCTP}$ or $\left[\alpha^{-32} \mathrm{P}\right] \mathrm{dATP}$. Pre-hybridization in $0.263 \mathrm{M} \mathrm{Na}_{2} \mathrm{HPO}_{4}, 1 \mathrm{mM}$ EDTA, $7 \%$ SDS, and $1 \%$ BSA at $65^{\circ} \mathrm{C}$ lasted for $4 \mathrm{~h}$, and the probe was added and left overnight at $65^{\circ} \mathrm{C}$. The membrane was washed in $0.25 \mathrm{M} \mathrm{Na}_{2} \mathrm{HPO}_{4}, 1 \%$ SDS, $2 \times \mathrm{SSC}, 0.1 \%$ 


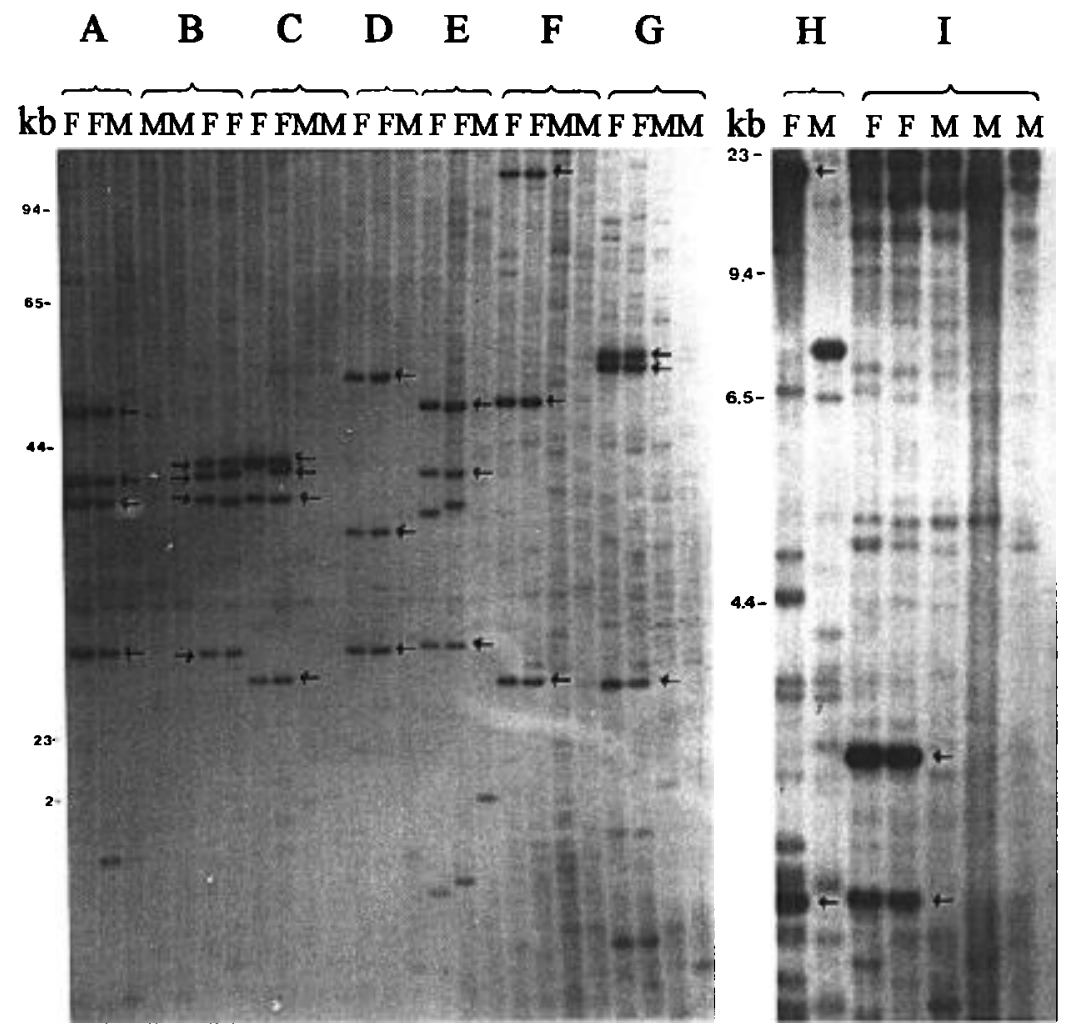

FIG. 1. Parrot DNA hybridized with human minisatellite probe 33.15. Female-specific bands are shown with arrows. (A) Ara auricollis, (B) Ara chloroptera, (C) Ara macao, (D) Ara manilata, (E) Ara maracana, (F) Ara nobilis, (G) Anodorhynchus hyacinthinus, (H) Anodorhynchus leari, (I) Cyanopsitta spixii. F = female, $M=$ male.

TABLE 2. Molecular size of the sex-linked bands in South American parrots.

\begin{tabular}{lcl}
\hline \hline \multicolumn{1}{c}{ Species } & $\begin{array}{c}\text { Number } \\
\text { of bands }\end{array}$ & $\begin{array}{c}\text { Molecular size } \\
\text { (kb) }\end{array}$ \\
\hline Anodorhynchus & & \\
$\quad$ hyacinthinus & 3 & $3.1 ; 5.1 ; 5.2$ \\
Anodorhynchus leari & 2 & $3.1 ; 18.5$ \\
Ara ararauna & 2 & $1.9 ; 2.5$ \\
Ara auricollis & 4 & $2.7 ; 3.7 ; 3.9 ; 4.8$ \\
Ara chloroptera & 4 & $2.7 ; 3.7 ; 4.0 ; 4.1$ \\
Ara macao & 4 & $2.5 ; 4.0 ; 4.1 ; 4.3$ \\
Ara manilata & 3 & $2.7 ; 3.5 ; 4.0$ \\
Ara maracana & 3 & $2.7 ; 3.9 ; 4.6$ \\
Ara nobilis & 3 & $2.5 ; 4.7 ; 11.5$ \\
Aratinga aurea & 2 & $3.7 ; 7.6$ \\
Aratinga acuticaudatta & 3 & $2.9 ; 3.6 ; 4.6$ \\
Aratinga leucophthalmus & 2 & $3 ; 7.6$ \\
Aratinga mitrata & 3 & $2.9 ; 3 ; 10.5$ \\
Aratinga solstitialis & & \\
$\quad$ auricapilla & 3 & $4.2 ; 5.0 ; 6.0$ \\
Aratinga solstitialis & & \\
jandaya & 3 & $4.1 ; 5.2 ; 5.8$ \\
Cyanopsitta spixii & 2 & $3.1 ; 3.5$ \\
Guaruba guarouba & 2 & $2.8 ; 5.7$ \\
Nandayus nenday & 3 & $3.9 ; 4.8 ; 6.0$ \\
\hline
\end{tabular}

SDS and in $1 \times \mathrm{SSC}, 0.1 \%$ SDS at $65^{\circ} \mathrm{C}$. The filter was then autoradiographed at $-70^{\circ} \mathrm{C}$ using Kodak RX film with one or two intensifying screens.

Results.-A pattern of two to four intense sex-specific bands was detected with the 33.15 probe in all females studied in the genera Ara and Aratinga and also in females of Anodorhynchus hyacinthinus, A. leari, Cyanopsitta spixii, Guaruba guarouba, and Nandayus nenday (see Fig. 1). These intense bands also were present in some previously unsexed individuals of Aratinga solstitialis auricapilla, A. s. jandaya, and A. mitrata (Table 1). Each species showed unique patterns of female-linked bands according to their molecular size (Table 2); these species-specific profiles are a potential tool for species identification. Female-linked bands also were observed in long-tailed species even when other restriction enzymes were used (data not shown). Sex-linked bands were absent in known females of eight species of Amazona and of Pionus menstruus, Deroptyus accipitrinus, Pionites leucogaster, Pionopsitta pileata, Pyrrhura egregia, P. frontalis, P. picta, and Triclaria malachitacea. We used $M b o I$ for members of Amazona because this enzyme produced more polymorphic DNA fingerprint profiles; even when 
we used HaeIII, no sex-linked fragments were observed (data not shown).

Discussion.-Until recently, only three methods of sex identification were available for birds: fecal hormone assay, chromosome analysis, and laparoscopy. Hormone analyses vary with reproductive condition and thus are age and season dependent. Chromosome analysis is reliable but time consuming, and in many occasions appropriate metaphase cells cannot be found for analysis without repeated attempts. Birds have to be handled twice for karyotyping, once for removing a sample of feathers and a second time for collecting the growing feather pulp. Because laparoscopy is a surgical procedure, birds are exposed to anesthesia and to the risks of surgery.

Recently, several DNA techniques have been developed for sex identification in birds (de Kloet and de Kloet 1992, Griffiths and Tiwari 1993, May et al. 1993). Griffiths and Tiwari (1995) determined the sex of the last Spix's Macaw (Cyanopsitta spixii) from shed feathers that were collected in the wild and used as a source of DNA for PCR amplification. In our application of DNA fingerprinting in South American parrots, we identified female-specific intense bands in some species using the human minisatellite probe 33.15 (Miyaki et al. 1992, 1993). Other authors also have detected sex-specific bands in DNA fingerprinting of birds using probe 33.15 (Rabenold et al. 1991, Longmire et al. 1992) and probe 33.6 (Graves et al. 1993). Although probe 33.15 could not be used to identify the sex of all the species we studied, it was invaluable for sexing macaws (Ara, Anodorhynchus, and Cyanopsitta) and conures (Aratin$g a$ and Nandayus). These genera belong to the "long, point-tailed" group and are considered to be closely related. Our method could not be used to sex the short-tailed parrots in the genus Amazona, and our data suggest that it also was not adequate for sexing other short-tailed species such as Pionus menstruus, Pionites leucogaster, and Pionopsitta pileata (which has sexually dimorphic plumage), as well as the "long, wide-tailed" Deroptyus accipitrinus and Triclaria malachitacea (the latter has sexually dimorphic plumage). The absence of female-linked bands was not due to the fact that a different restriction enzyme was applied. No sex-specific pattern was detected in the three species of Pyrrhura we studied, each of which has a long, sharp-pointed tail.

In all cases where we performed karyotyping, we confirmed that the intense band pattern was present in all females and absent in males. Because of the difficulties inherent in chromosome analysis (i.e. lack of growing feathers and failure to obtain appropriate metaphase cells), it was impossible to determine the sex of many of the species that we studied with probe 33.15. However, the agreement between the DNA results and the cytogenetic data in all species for which both studies were performed suggests that the pat- tern of a few intense bands detected in some unsexed individuals was restricted to females.

Little is known about the phylogenetic relationships of psittacines. The available data are based on chromosomal evolution (Valentine 1990, Christidis et al. 1991), albumin (Sibley 1960), and the cytochrome$b$ gene (Birt et al. 1992, Leeton et al. 1994). Based on karyotype correlations, Valentine (1990) proposed an early separation of Amazona from other genera. Based on habitat exploration, Montón (1977) suggested that the short-tailed and the long-tailed birds have behavioral differences. The presence of $\mathrm{w}$-chromosome-linked minisatellite sequences in most longand sharp-tailed New World psittacines, and their absence in the short-tailed species, provide support for the separate evolution of these two groups. Preliminary analysis of mitochondrial gene (12S and 165 rDNAs and cytochrome- $b$ ) sequences of nine species of Brazilian parrots also supports the separation of the long- and short-tailed species (Miyaki 1996).

Acknowledgments.-This work was funded by FAPESP, CNPq, and CAPES (Brazil). We thank T. Burke for a visit to his lab; O. Hanotte and C. F. M. Menck for their constant support; P. F. Flecha for invaluable discussion; and L.A. Labruna (Parque Ecológico do Tietê, SP), A. L. V. Nunes (Sorocaba Zoo), N. Kawall, L. Maluf, A. Marra, A. Vertematti, C. Isoldi, and M. Silva (aviculturists, Brazil), L. Sanfilippo (São Paulo Zoo), and M. I. Bampi (IBAMA) for parrot blood samples. C. Y. M. has a Fundo BUNKA/ 90 prize. The Jeffreys' probes 33.6 and 33.15 are the subject of patent No. GBA 2166445 and worldwide patents for commercial diagnostic use. We also thank Associate Editor Allan Baker and two anonymous reviewers for comments and editorial suggestions.

\section{Literature Cited}

Birt, T. P., V. L. Friesen, J. M. Green, W. A. MoNTEVECCHI, AND W. S. DAVIDSON. 1992. Cytochrome- $b$ sequence variation among parrots. Hereditas 117:67-72.

BroCK, M. K., AND B. N. WhITE. 1992. Application of DNA fingerprinting to the recovery program of the endangered Puerto Rican Parrot. Proceedings of the National Academy of Sciences USA 89:11121-11125.

BRUFORD, M. W., O. HANOTTE, J. F. Y. BRoOKFIELD, AND T. BURKE. 1992. Single locus and multilocus DNA fingerprinting. Pages 225-269 in Molecular genetics analysis of populations. A practical approach (C. A. R. Hoelzel, Ed.). Oxford University Press, New York.

BURKE, T., AND M. K. BRUFORD. 1987. DNA fingerprinting in birds. Nature 327:149-152.

Christidis, L., D. D. Shaw, AND R. SCHOdDE. 1991. Chromosomal evolution in parrots, lorikeets and cockatoos (Aves: Psittaciformes). Hereditas 114:47-56. 
DE Kloet, D. H., AND S. R. DE KLOET. 1992. Molecular determination of the sex of parrots. Focus 14:106-108.

Duarte, J. M. B, And R. Caparroz. 1995. Cytotaxonomic analysis of Brazilian species of the genus Amazona (Psittacidae, Aves) and confirmation of the genus Salvatoria (Ribeiro, 1920). Brazilian Journal of Genetics 18:623-628.

Graves, J., J. Ortega-Ruano, and P. J. B. Slater. 1993. Sex ratio of chicks in the Shag Phalacrocorax aristotelis determined by a female-specific band in DNA fingerprinting. Ibis 135:470-472.

GRIFFITHS, R., AND B. TIWARI. 1993. The isolation of molecular genetic markers for the identification of sex. Proceedings of the National Academy of Sciences USA 90:8324-8326.

GriffithS, R., AND B. TiwARI. 1995. Sex of the last Spix's Macaw. Nature 375:454.

Jefrreys, A. J., V. Wilson, AND S. L. TheIN. 1985. Hypervariable "minisatellite" regions in human DNA. Nature 314:67-73.

LeETon, P. R. J., L. Christidis, M. WESTERMAN, AND W. E. Boles. 1994. Molecular phylogenetic affinities of the Night Parrot (Geopsittacus occidentalis) and the Ground Parrot (Pezoporus wallicus). Auk 111:833-843.

LONGMIRE, J. L., G. F. GEe, C. L. HARDEKOPF, AND G. A. MARK. 1992. Establishing paternity in Whooping Cranes (Grus americana) by DNA analysis. Auk 109:522-529.

Mathe, J., C. Eisenmann, And A. Seitz. 1993. Paternity testing of endangered species of birds by DNA fingerprinting with non-radioactive labelled oligonucleotide probes. Pages 387-393 in DNA fingerprinting: The state of the science ( $S$. D. J. Pena, R. Chakraborty, J. T. Epplen, and A. J. Jeffreys, Eds.). Birkhäuser Verlag, Basel, Switzerland.

May, C. A., J. H. Wetton, And D. T. Parkin. 1993. Polymorphic sex-specific sequences in birds of prey. Proceedings of the Royal Society of London Series B 253:271-276.

MIYAKI, C. Y. 1996. Um estudo filogenético de psitacídeos (Psittaciformes, Aves) baseado em sequências de genes mitocondriais. Ph.D. disser- tation, Universidade de São Paulo, São Paulo, Brazil.

MiYAKI, C. Y., O. HanotTe, A. WajnTAL, AND T. BURKE. 1992. Sex typing of Aratinga parrots using the human minisatellite probe 33.15. Nucleic Acids Research 20:5235-5236.

MrYAKI, C. Y., O. HANOTTE, A. WajnTAL, AND T. BURKE. 1993. Characterization and applications of multilocus DNA fingerprinting in Brazilian endangered macaws. Pages 395-401 in DNA fingerprinting: The state of the science (S. D. J. Pena, R. Chakraborty, J. T. Epplen, and A. J. Jeffreys, Eds.). Birkhäuser Verlag, Basel, Switzerland.

MiYaKi, C. Y., O. HanotTe, A. WajnTAL, and T. BURKE. 1995. DNA fingerprinting in the endangered parrot Aratinga guarouba and in other Aratinga species. Brazilian Journal of Genetics 18: 405-412.

MONTON, M. 1977. Algunos aspectos significativos en la adaptacion de los psitácidos de Sudamérica. Revista del Parque Zoologico de Barcelona 30:19-22.

Rabenold, P. P., K. N. Rabenold, W. H. Piper, J. HAYDOCK, AND S. W. ZACK. 1991. Density-dependent dispersal in social wrens: Genetic analysis using novel matriline markers. Animal Behaviour 42:144-146.

SAmbrook, J., E. F. Fritsch, AND T. Maniatis. 1989. Molecular cloning: A laboratory manual. Cold Spring Harbor Laboratory Press, Cold Spring Harbor, New York.

SIBLEY, C. G. 1960. The electrophoretic patterns of avian egg white proteins as taxonomic characters. Ibis 102:215-284.

VAlentine, M. 1990. Chromosome Analysis. Pages 127-131 in Genus Amazona (J. Stoodley and P. Stoodley, Eds.). Bezels Publications, Portsmouth, United Kingdom.

Wetton, J. H., R. E. Carter, D. T. Parkin, and D. WALTERS. 1987. Demographic study of a wild House Sparrow population by DNA fingerprinting. Nature 327:147-149.

Received 15 July 1996, accepted 10 February 1997. Associate Editor: A. J. Baker 